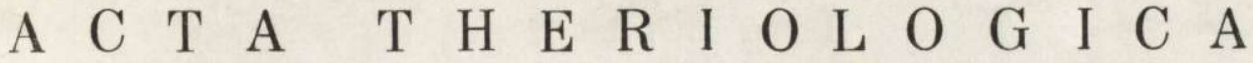 \\ VOL. XII, 35: 495-501 \\ BIAŁOWIEŻA \\ 30.XII.1967
}

Zdzisław PUCEK

\section{The Most Important Problems for Further Studies on European Bison}

\author{
Bisoniana XXXV
}

\begin{abstract}
Further restitution of the European bison makes it necessary to undertake wide-scale ecological research, in order to make it possible to envisage further enlargement of the range of the species, estimate maximum population density in different ecosystems and elaborate principles for the management of free-living populations. The following problems seems to be the most important for further studies: Population structure and the degree to which the habitat is utilized, activity and behaviour, repreduction biology, the place and role of the European bison in forest ecosystems of the temperate zone, adaptability of the European bison. On these problems the research efforts should be concentrated in next years. Other problems such as: anatomy, the bases of physiology, rate of growth and development, evaluation of the degree of domestication, hybridisation of the European bison with domestic cattle are not of fundamental importance for further spreading and management of wild population of European bison.
\end{abstract}

\section{INTRODUCTION}

The material from the symposium of the Mammal Section of the Polish Zoological Society published in this issue contains a review of what we know about the European bison and analyses the current state of research work on this species in Poland and in the world. The review does not of course pretend to a monographical and complete treatment of this animal. The review made, together with earlier studies, clearly reveals that in some fields research on Bison bonasus has not as vet been undertaken at all or only just initiated (particularly in the field of biology and ecology). The causes of this state of affairs are more than cbvious; at the time when the ecology of other ungulates was being investigated by modern methods, the Bison bonasus no longer occurred in free state.

Many authors have drawn attention earlier on to the insufficient knowledge we have of the bison and suggested that definite research work should be undertaken. Remarks of this kind are to be found in 
elaborations of recent years, both in monographs (such as, e.g. G e p t$\mathrm{n}$ e $\mathrm{r}$ et al., 1960) or in the materials of the Polish-Soviet conferences devoted to breeding of the Bison bonasus in the Białowieża Primaeval Forest (cf. Dementev, 1966; S cibor, 1966). Some of the papers read at the symposium referred to also strongly emphasise these questions (e.g. B orowski et al., 1967; Gill, 1967; Krasiński \& R a c z y ń ski, 1967). These authors' suggestions have been used in the present presentation of problems put forward as important in further studies on the European bison.

It is not only a question in investigations of these studies of obtaining a general knowledge of the animal. In at least certain parts of the bison's ${ }^{1}$ ) contemporary range the conflicting interests of these animals and forest management are becoming evident. A knowledge of the European bison's biology will be equally essential in the future when it becomes possible to speak of its reintroduction to the list of game animals. The present state of knowledge of the European bison does not permit of a rational solution of these questions. Serious difficulties have today arisen with regard to finding an answer to the most important problems concerned with further restitution of $B$. bonasus. In particular there are no scientific grounds for: 1. Establishing the principles of rational planning of further enlargement of geographical range of $B$. bonasus and its acclimatisation in new areas, both within and beyond the original range of this species; 2. Assessment of the permissible population density of the Bison bonasus in defined ecosystems of the temperate zone; 3 . Forecasting the role of the European bison as a new component of the ungulates minor community; 4. Forecasting principles for management of free-living populations of this species in order to obtain their maximum productivity. In these circumstances it is of course obviously essential to undertake wide-scale research work, particularly in directions which have hitherto been neglected. The conditions for such work are indeed particularly favourable. It is again becoming possible to observe free-living bison populations reintroduced into cultivated or semi-natural forest ecosystems in several part of the world, in Poland and the Soviet Union.

It is of course impossible to fill in all the gaps in our knowledge of the bison streight away. It therefore becomes an objective necessity to select the most essential problems for scientific management of future development (increase, regulation) of the head of bison in the world.

The more important problems set out below require solution within the next few years if the monographic outline of our knowledge of the bison is to be as complete as possible. On account of immediate and future needs two groups of problems have been distinguished: I particularly important problems concerned with the biology and ecology of the European bison on which the efforts of research workers should primarily be concentrated, and II - other problems, the continuation or undertaking of which should not be limited in any way, but which are not of first importance to further restitution of the Bison bonasus.

1) The word "bison" is used throughout the text of this article in the meaning of "European bison" or"wisent", 


\section{PARTICULARLY IMPORTANT PROBLEMS}

Ecological studies should be of first importance in research on the bison. This is a field which is particularly neglected, of course for understandable reasons. The following suggestions have therefore been limited to this field. The problems detailed below are important in this group:

\section{Population structure and degree to which the habitat is utilised}

When this problem is comprehensively treated it includes such questions as: 1.1 - Age and sex composition of the population. $1.2-$ Size and number of herds depending on population density and the season of the year. 1.3 - Seasonal changes in the spatial structure of the population. 1.4 - Ways in which the area is penetrated (concentrations, residence, migration). 1.5 - Size of the area occupied by a herd. 1.6 - Social structure - (system of hierarchical relations) in the herd.

\section{Activity and behaviour}

The problem includes such questions as: 2.1 - Daily activity rhythm. 2.2 - Seasonal variations in activity - both locomotor and food activity. 2.3 - The behaviour of bison in different biotopes and seasons, attitude to man.

\section{Reproduction biology}

These questions have been fairly well examined, in as far as bison living in enclosed reserves are concerned $(\mathrm{Z} \mathrm{a} \mathrm{b} \mathrm{l} \mathrm{o} \mathrm{c} \mathrm{k} \mathrm{i,} \mathrm{1957;} \mathrm{J} \mathrm{a} \mathrm{c} \mathrm{z} \mathrm{e} \mathrm{w-}$ ski, 1958; Krasiński \& Raczyński, 1967). Some aspects of reproduction can in fact only be observed under such conditions. Longterm investigations of reproduction in free-living populations are of immense importance to forecasts of any kind as to increase of head of different populations of the European bison over the area of its living space, and also of the average increase in numbers of this species in the world. In consequence the following questions are significant here: 3.1 - Comparison of reproduction potential of European bisons living in reserves and in freedom. 3.2 - Estimation of the reproduction potential (natality) of free-living populations under different habitat conditions, and in comparison with the period before the First World War, when bison were still living wild in the Białowieża Primaeval Forest. 3.3 - Variations in the reproduction potential of free-living populations of the bison in time. 3.4 - Sexual maturation and the sexual cycle morphological and physiological studies on the attainment of sexual maturity and sexual activity over the yearly cycle are particular necessary here. 3.5 - Causes and mechanism of failure to calve and the sterility of cow bison, occurrence of postpartum oestrus.

4. The place and role of European bison in the forest ecosystems of the temperate zone

Of recent years foresters have raised the problem of the damage done by bison in deciduous treestands and cultures. Speculative calculations 1 bison $=5$ red deer $=25$ roe deer have been put forward in this 
connection. In a similarly arbitrary way it has been assumed that for instance, the optimum density of bison in the Białowieża Primaeval Forest should be $4-5$ animals per 1000 ha and that the sex ratio should be kept at 1 bull : 4 cow (S c i b o r, 1966).

These data are too arbitrarily assumed, as is shown for instance by comparing corresponding data for the Moscow district $-\mathrm{Z} \mathrm{a} \mathrm{b} \mathrm{lock} \mathrm{a-}$ ja (1957) accepts permissible density of all ungulates up to 40 head per 1000 ha. A leksandrov \& Golgofska ja demonstrate (1961) that up to 50 bisons per 1000 ha can live in the reserve in the Caucasus Mountains. There is no doubt that there are great differences in food supply between habitats. It is also probable that the conditions in the Białowieża Primaeval Forest do not form an optimum habita: for the bison to live in (W r ó b l e w s k i, 1927; Z a b l o c k a j a, 1957). The indices accepted, however, would appear to be far too low, and it therefore becomes essential to define these indices for different parts of the range of $B$. bonasus in order to obtain the scale of their habitat capacity in relation to all the herbivorous ungulates and especially $B$. bonesus. This is directly connected with further enlargement of the European bison's range, its effect on the total production of different forest ecosystems and therefore the degree of the demage done. The following problems arise in this connection: 4.1 - The composition of the bison's food in different types of forest and in different parts of its contemporary range. 4.2 - Seasonal variations in the percentage of green and shrub-like plants in the bison's food. 4.3 - Daily food requirements in different seasons. 4.4 - Preferences for defined types of forest. 4.5 Seasonal variations in the food supply available to bison in the biotopes which they prefer.

Not until a detailed analysis has been made of the European bison's food requirements will it be possible to estimate the species' maximum density in a given area.

The scope of this problem also takes in other but no less important questions such as, e.g. 4.6 - Assessment of the effect of the bison's feeding has on treestands, taking into consideration the ways, extent and season of tree barking, the degree of harmfulness to different species of trees caused by the barking and in consequence - the effect of barking on the treestands (demages to forest-forming or to additional trees in the forest). 4.7 - The effect of the way in which food is supplied to European bison in the winter has on changes in the spatial structure of the population (e.g. - on concentration near feeding places) and in consequence on increasing demage to forest in the immediate vicinity of feeding places. 4.8 - The role of $B$. bonasus as a new component in ungulate community.

5. Determination of the suitability of different forest ecosystems as a habitat for the European bison both within and outside the limits of its contemporary geographical range

This is an important problem on account of the future prospects of enlarging the bison's living space in the world, or its acclimatisation in new areas. 


\section{Adaptability of the European bison}

We are re-introducing the European bison into nature and forcing it to live in forest ecosystems which are today far from being natural. Only small fragments remain of the former vast primaeval forests, and even these are in addition seriously changed and transformed as the result of human management. It is therefore of great importance to study the ways in which the bison adapts itself to such changed habitats (see also $\mathrm{Zablocki}$, 1963). Observations of the reproduction and condition parameters and the behaviour of free-living populations of bison in different biotopes over the area of its present-day geographical range may provide an indication as to which parts are preferable, and to possible future artificial enlargement of this area by new territories.

\section{OTHER PROBLEMS}

It would be possible to mention many other important research problems, but the list should be limited to those which are particularly evident in the light of the review made on the symposium mentioned above.

\section{Monographical elaborating the anatomy of the European bison}

Studies, made chiefly in Poland in this direction, should be completed as soon as possible in view of their fundamental documentary importance. Elaboration of the anatomy and histology of the genital system is urgently required for the purposes of the reproduction biology. It is difficult to trace changes in coat - which usually form an important guide to the general condition of the animal - on account of the lack of comprehensive elaborations of the integumental system.

\section{Bases of the normal physiology}

Whole aspects of the bison's physiology have as yet remained unelaborated (Gill, 1967), the scanty head of populations of this species in the world forming the chief obstacle here. There are in consequence no data available on the functionning of the heart and respiratory system. which are of such vital importance in any physiological research. We know nothing of skin temperature, the properties of embryonic development and the early postnatal stages, lactation and the properties of semen at different seasons etc.

Digestibility and assimilation of different natural foods are particularly important and require basic examination.

\section{Rate of growth and individual development}

The growth tempo of the European bisons, remained almost untouched in literature. It is important for comparison with the growth rate of hybrids of European bison and domestic cattle. Studies on postnatal development (including age of maturity and reproduction, longevity in 
both sexes etc) are of great significance in calculation of the increase and productivity of the bison' population, and with favourable increase in numbers, also their optimum utilisation.

\section{Evaluation of the degree of domestication of the European bison}

The existence of free-living herds and simultaneous maintenance of reserve stock in enclosed reserves makes it possible to evaluate the degree to which the bison has become domesticated during the past long period of its life in the latter. Some differences have been recently observed in reproduction ( $\mathrm{Kr}$ a siński \& R a c zyński, 1967). It is essential to continue these comparative studies, aiming at obtaining the completest possible picture of the reproduction physiology and biology of the bison, and thus the sexual activity of both sexes in different seasons, sexual maturation, oestrus, pregnancy, lactation, suckling the young etc. in reserves and in free-living populations.

Another problem well suited to assessing differences in the course taken by various physiological processes in reserves and in freedom is the rate and course of moulting.

\section{Attempts at practical utilization of the European bison by erossbreeding with domestic cattle}

The experiments so far made in this field were limited to a few breeds of cattle: Schwytz, Grey Ukrainian, Lowland Black-and-White, Red Polish (K rasins ka, 1967). The results are sufficiently encouraging to make it worth while continuing this work with other breeds, especially those better suited for meat production.

These suggestions, accepted in cutlined form, as the end result of the Białowieża symposium on the European bison, do not of course exhaust the possible programme of research on this species. They are not in fact aimed at this. It would however appear that the selected problems are those most important and simultaneously capable of realization in the next few years. The publication of these discussions has been dictated by the hope that they may prove useful to zoologists studying the European bison not only in the Białowieża Primaeval Forest, but also in other breeding centres of this species.

\section{REFERENCES}

1. Aleksandrov V. N. \& Golgofskaja K. Ju., 1965: Kormovye ugod'ja zubrov Kavkazskogo zapovednika. Tr. Kavkaz. gos. zapov., 8: 129-154.

2. Borowski S., Krasiński Z. \& Miłkowski L., 1967: Food and role of the European bison in forest ecosystems. Acta theriol, 12, 25: 367-376.

3. Dementev G. P., 1966: Problemy obščego uveličenija čislennosti Evropejskogo zubra. (In book: „Hodowla żubrów w Puszczy Białowieskiej”). Min. Leśn. i Przem. Drzewn., Zarząd Ochr. Przyr.: 77-85.

4. Geptner V. G., Nasimovič A. A. \& Bannikov A. G., 1961: Mlekopitajuščie Sovetskogo Sojuza. Vysšaja Škola, 1: 338-417. Moskva. 
5. Gill J., 1967: The physiological properties of the European bison. Acta theriol., 12, 23: $349-360$.

6. Jaczewski Z., 1958: Reproduction of the European bison, Bison bonasus (L.), in reserves. Acta theriol., 1: $333-376$.

7. K rasińska M., 1967: Interspecific hybridization between Bos taurus dom. L. and Bison H. Smith. Przegl. zool., 11, 1: 79-94 [In Polish with English summ.].

8. Krasiński Z. \& Raczyński J., 1967: The reproduction biology of the European bison living in reserves and in freedom. Acta theriol, 12, 29: 407444.

9. S c i b or J., 1966: Hodowla żubra w Polsce. (In book: „Hodowla żubra w Puszczy Białowieskiej"). Min. Leśn. i Przem. Drzewn., Zarząd Ochr. Przyr.: 19-30. Warszawa.

10. Wróblewski K., 1927: Żubr Puszczy Białowieskiej. Nakł. Ogrodu Zool. w Poznaniu. Wyd. Polskie: $1-232+$ XVI.

11. Zablockaja L. V., 1957: Pitanije i jestestvennye korma zubrov. Tr. Prioksko-terrasn. gos. zapov., 1: 66-143.

12. Zablockij M. A., 1957: Nekotorye biologičeskije osobennosti zubra i ih izmenenije v uslovijah zagonnogo soderžanija. Tr. Prioksko-terrasn. gos. zapov., 1: $5-65$.

13. Zablockij M. A., 1965: Zubr u kulturnyj landšaft. [In collected papers: „Voprosy ohotnič'ego hozjajstva SSSR”]: 55-63. Kolos, Moskva.

Received, May 2, 1967.

Polish Academy of Sciences,

Mammals Research Institute;

Białowieża, Poland.

\section{Zdzisław PUCEK}

\section{PROBLEMY SZCZEGÓLNIE WAŻNE W BADANIACH NAD ŻUBREM}

\section{Streszczenie}

Dalsza restytucja żubra wymaga podjęcia szeroko zakrojonych badań ekologicznych, aby można było przewidywać rozszerzenie areału, oceniać maksymalne zagęszczenie populacji w określonych ekosystemach i opracować zasady gospodarowania wolnymi stadami żubrów. Wyróżniono dwie grupy problemów: A - szczególnie ważne, B - inne. Do pierwszej wchodzą: 1 - Struktura populacji a stopień wykorzystania środowiska, 2 - Aktywność i behaviour, 3 - Biologia rozrodu, 4 - Miejsce i rola żubra w ekosystemach leśnych strefy umiarkowanej, 5 Adaptacyjne właściwości żubra. Wokół tych problemów winny się koncentrować wysiłki badawcze w najbliższych latach. Inne problemy, jak: anatomia żubra, podstawy fizjologii, tempo wzrostu i rozwoju, ocena stopnia domestykacji, hybrydyzacja żubra $\mathrm{z}$ bydłem domowym - nie mają zasadniczego znaczenia dla dalszego rozprzestrzeniania się żubra na świecie i kierowania wolnymi populacjami tego gatunku. 